\title{
How much management is enough? Stakeholder views on forest management in fire-prone areas in central Portugal
}

\section{Introduction}

The international and national political agendas regarding forests are changing so that they include a greater integration of global challenges, local needs and interests. These new agendas have brought new stakeholders onto the scene as well as a whole set of multiple perceptions, values, attitudes and interests regarding forests and the forest sector came alongside (Fabra-Crespo, et al. 2012). The progress towards Sustainable Forest Management (SFM) is now anchored within the recognition of the need to work together with forest stakeholders and to take their perceptions, preferences and behaviours into consideration.

Rametsteiner and Kraxner (2003: 43) argue that «Whatever the actual state of Europe's forests, it is the public's view on issues that counts possibly as much in forest policy and business». This statement underlines the importance of assessing social perceptions when it comes to understanding forest management views and practices as well as the importance of increasing public awareness about the socio-economic, environmental and cultural relevance of forests (Dolisca et al., 2007). It also identifies areas of agreement and conflict among the various forest stakeholders (Elands and Wiersum, 2001; Ní Dhubháin et al., 2008). Fabra-Crespo, et al. (2012) argue that talking to the people involved in the forest sector at various levels is essentially the key to effective management of natural resources. In fact, it is essential when it comes to foster mutual understanding, decision making and overall management of forests. This may also have an important impact in increasing societal acceptance and implementation of decisions (Valkepää and Karpinnen, 2013).

The aim of this paper is to discuss the results of a survey on people involved in the forest sector. It is based on qualitative variables about forest values and forest management practices in areas of high fire risk. The main criteria in selecting the case study is to focus upon smallscale private holdings of maritime pine and eucalyptus. For this reason it was chose the municipality of Mação located in the central region of Portugal.

Following a theoretical debate outlining the various types of forest owners, the values of the forest and the issues affecting forest management (Section 2), the methodology is presented (Section 3). Section 4 discusses the results of the survey, which are discussed in the light of the theoretical assumptions (Section 5). 


\section{Theoretical assumptions}

Based on public opinion surveys carried out in various EU countries in the last 20 years (e.g. O'Leary and Elands, 2002; Wiersum and Elands, 2002; EC, 2002; Rametsteiner and Kraxner, 2003; Elands et al., 2004; Wiersum et al., 2005; Rametsteiner et al., 2007; EC, 2009; Elands and Praestholm, 2008), and aiming to understand the values underlying forest management practices, this research was guided by three main hypotheses: 1) a shift from classic owners to hobby owners or indifferent owners is occurring in private small-scale forest holdings; 2) forests and forestry are increasingly valued for their environmental amenities; 3) the absence of forest management is a major driving force for wildfires.

As far as the first hypothesis is concerned, it can be stated that in the past, both in Europe as in Portugal, small-scale forest owners have been economically dependent on their forests, as a complementary activity to farming and for the provision of forest products such as forage and fuel wood. Nowadays, these owners (due to their age) or their heirs are demonstrating a relatively low interest when it comes to the economic role of their forests. O'Leary and Elands (2002) argue that the majority are becoming either disinterested or environmentalist in their objectives. The economic dependence upon forest resources decreased drastically due to rural out-migration and a decline in primary activity. This decline is in line with changes within broader rural development strategies, where a transition is taking place from a rural modernization perspective to a rural restructuring one (Wiersum et al., 2005).

In general terms, there are a number of factors responsible for the logistics of forest ownership which range from more tangible aspects, such as the conditions and the characteristics of forests, to intangible criteria, such as the societal value given to the forest, or the importance of the forest as a legacy or the future perspectives of the forest (Kline et al., 2000; Bieling, 2004; Boon et al., 2004; Wiersum, et al., 2005; Elands and Praestholm, 2008). While the former factors can be analysed through quantitative data, the latter are better understood through the use of a more qualitative approach, namely through the assessment of the forest owners' perceptions.

Academic literature shows that the global current profile of small-scale forest owners may be summarized in four main types. The first type - the classic forest owner - represents the owners that are mostly concerned with the financial return from their forests; however legacy also plays an important role (Boon et al., 2004; Elands and Praestholm, 2008). The forest owners may also value the environmental and recreational aspects of forests, evolving to type 2 - multi-objective owner. The third type is the hobby or environmentalist owner, mostly valuing the environmental 
and the aesthetic role of forests. Finally, the fourth type is the indifferent or passive owner, who has no further objectives besides keeping the forest property within the family. Wiersum et al. (2005) state that hobby owners and indifferent owners are becoming more and more important across Europe. In fact, the social changes related to rural-urban migration, and the intergenerational transfer of the land, suggest a potential increase of the indifferent forest owners in the future and they will replace the more traditional type of classic forest owners (Heino and Harvonen, 2003; Wiersum et al., 2005). This may have important effects on forestry purposes and management practices (Heino and Harvonen, 2003).

Portugal follows in line partly these aforementioned trends in which the presence of indifferent owners is increasing, but the environmental and recreational functions are still undervalued by forest owners (Baptista and Santos, 2005; Radich and Baptista, 2005). This is especially true in the central and northern regions of Portugal, where small-scale forest holdings prevail and where forest owners are considering zero intervention as the only economically viable option for their land.

As far as the increasing social value attributed to the environmental functions of the forest is concerned, important changes have taken place in Europe over the past decades. The productive function of the forest, related to the production of timber and other tangible goods, is a major role of forests in fulfilling the increasing social needs for raw materials and also in sustaining the rural economy. But forests are increasingly perceived as green and natural environments and less as an economic activity or a service provider (O'Leary and Elands, 2002, Heino and Harvonen, 2003; Rametsteiner and Kraxner, 2003; Boon et al., 2004; Elands et al., 2004, Ní Dhubháin et al., 2008). This has been confirmed in several surveys, that have been carried out in Europe (Elands and Wiersum, 2001; Elands et al., 2004; Wiersum et al., 2005; Ní Dhubháin et al., 2008). The European cross-study: 'Shaping forest communication in the European Union: public perceptions of forests and forestry' concluded that European public opinion on forestry had «shifted viewpoint from a traditional commodity-based and recreational management demand to a demand for greater protection and management for ecosystem services» (EC, 2009: xix).

The preservation of biodiversity represents indeed a key concern of the EU public opinion about forests (Rametsteiner and Kraxner, 2003; EC, 2009; Forestry Commission, 2011), and this has also generated a more critical eye towards the use of resources (EC, 2009). In this sense, people are demanding more close-to-nature forest management practices (Ramesteiner and Kraxner, 2003; Bieling, 2004; Fléchard et al., 2006; EC, 2009). The valuation of the 
environmental role of forests is also visible in the increasing importance attributed to the SFM, to the role of forests in mitigating climate change and in protecting from natural disasters (EC, 2009). The survey from the EC (2009) also demonstrated showed that people in Southern Europe are more concerned with deforestation and climate change than with the economic use and the actual value of forests.

Despite the centrality of the environmental functions of forests within EU public opinion, the significance that people attribute to those functions may vary greatly. For example, Ní Duhbháin et al. (2008) argue that social perceptions can be related to the history of the place, the history of forest itself and the geographical and socio-economic characteristics of the area. In Rametsteiner and Kraxner (2003) public opinion cross-study, it has been concluded that the productive function of forests is more valued in typical forest countries, such as Norway, Sweden and Austria. Moreover, another study in Ireland revealed that more positive perceptions about forestry were found in traditional forest areas when compared to planted areas (Ní Dhubháin et al., 2008). Some studies also identified major public opposition to forestry in afforestation areas, claiming that some afforestation practices do not respect local identity and landscape aesthetics (e.g. O'Leary et al., 2000; Fléchard et al., 2006).

The third hypothesis links the lack of forest management to the severity of forest fires. Wildfires are one of the largest threats affecting the Mediterranean region, and Portugal is at the top of the list of the most affected EU countries (JRC/EU, 2010). In terms of public opinion in Europe, forest fires are also perceived as a major hazard, especially in southern countries (EC, 2009). Public opinion in Portugal is unanimous in naming forest fires as the central threat. This was observed in European surveys (EC, 2009), in nationwide surveys (Colaço, 2006; Galante et al., 2009; Ribeiro et al., 2012; Coelho et al., 2012) and in small case-study surveys (Deus, 2010; Ribeiro et al., 2010).

In the Mediterranean region, wildfires are usually caused by anthropogenic factors (FAO, 2007). The official causes in Portugal are the negligent use of fire, especially in relation to farming and grazing practices, and arson (Damasceno and Silva 2007; Colaço, 2009). When we take national public opinion surveys into consideration, the same causes are highlighted, but arson is the cause mentioned most, followed by vandalism (Colaço, 2009; Galante et al., 2009).

But how the fires are ignited is only part of the problem. Wildfires tend to be intense in Mediterranean areas and the catastrophic fires that Portugal experienced in 2003 and in 2005 were also linked to the extreme meteorological situation and excessive near-ground fuel loads associated with the neglect of rural land (CNR, 2005; Pinho et al., 2005). Fires have been 
especially frequent in the maritime pine and eucalyptus forests in central-northern and southerncentral regions of Portugal, which are the main afforestation and reforestation species of the Mediterranean basin and are particularly flammable (Conacher and Sala, 1998; Fernandes, 2007). Rural out-migration triggered the advance of forests and of shrub land and became abandoned agricultural areas. This situation has promoted the spread of extensive areas of forest monoculture. Moreover, minimal forestry interventions needed for fire prevention are scarce in small-scale private forests and it is common that many forest owners intentionally choose not to do any work to their properties (Mendes, 2003; Radich and Baptista, 2005).

While it is consensual that the absence of forest management contributes to a real fire hazard, Galante et al. (2009) argues that there is a widespread feeling that there is no control over fire hazard in Portugal. Public awareness campaigns have been geared towards increasing citizens' responsibility (Damasceno and Silva, 2007), but people usually blame public authorities and to other forest stakeholders, thus downplaying their own responsibility. The same can be said for forest owners and forest or farmer associations (Galante et al., 2009).

\section{Research design}

A specially designed stakeholder perception survey was carried out in the municipality of Mação with the aim of assessing and understanding the different views of forest and forest management. The survey addressed the perceptions of various forest stakeholders, namely the national and regional decision-makers and technicians from public institutions within forest sector, the local decision-makers and technicians from governmental and non-governmental organizations and the forest owners and other members of the local community.

\subsection{Case study}

The municipality of Mação is located in the centre of Portugal, more precisely within a transition zone between the densely populated coastal regions and the depopulated interior areas (Figure 1). In the beginning of the 20th century, Mação had a highly diversified landscape supporting a variety of activities, including subsistence farming (e.g. olive production), grazing of sheep and goats and other forest related practices (e.g. timber production and resin extraction). In the 1950s and 1960s, large-scale migration (mainly to Lisbon) resulted in severe depopulation and a general abandonment of traditional activities.

The case study is a good depiction of the forestry setting of the central region of Portugal, which can be summarized as follows: 
- Small-scale forest holdings: forest land is mostly private and very fragmented (the average size of forest plots is less than 0.5ha). Mação has a land registry, but forest owners are either elderly (over 60 years old) and/or with no economic capacity for longterm investments (retired or low income jobs) or are people living in urban areas;

- Rural abandonment and forest encroachment onto agricultural areas: the very rapid rural depopulation that has occurred in Portugal since the 1950s and that has consequently left behind very depopulated and aged territories, has also led to the abandonment of agriculture, grazing and other rural activities and to the increase of forest plantations (eucalyptus) in former agricultural areas;

- Lack of forest management: traditional forest management, complementary to agriculture, grazing and cattle breeding, have declined significantly. Additionally, many landowners have no capacity or interest in investing in their properties.

- The frequency and severity of forest fires alongside the degradation of the land have had devastating effects: in 2003, wildfires consumed 18,134ha of forest (around $85 \%$ of the total municipal forest area) and $10 \%$ of the shrub land (AFN, 2010). Some areas were affected by repetitive wildfires, causing the reduction of vegetation cover, the loss of the top soil layer, the reduction of organic matter and the increase of shrubland and Cistus ladanifer. (Valente et al, 2011a).

In 2014, wildfires are still an imminent hazard in Mação due to mismanagement, dense and dry vegetation combined with an extremely dry climate and very strong winds. Fire hazards also led to huge investments made by the Municipal Council in terms of measures, equipment and infrastructures for forest protection against fires, such as water points, watch towers, a MACFIRE - System to monitor forest fires, a network of fire-breaks and paths and, more recently, the implementation of a network of strips for fuel management. The establishment of a forest association - AFLOMAÇÃO - and the implementation of Forest Intervention Areas (ZIF), described at Valente et al. (2013), are also examples of strategies to encourage forest management.

\subsection{Methodology}

The survey carried out in this research assesses different and potentially conflicting perceptions and views of forest management in Mação. The survey has integrated national and local decision-makers and technicians (technical perceptions) and a sample of forest owners and other inhabitants from Mação (social perceptions). Two questionnaires were used during 2010 
(first phase) and 2012 (second phase) by trained interviewers. National technicians were sent the questionnaire by email. The main questionnaire (Q1 - Appendix 1) was applied to all respondents and the second questionnaire (Q2 - Appendix 2) was only applied to forest owners. The questions were prepared on the basis of the input from several experts in the field, including international and national academics, as well as forest technicians. Q1 included 18 main questions and 29 sub-questions. The majority of the questions were closed questions directed at the forest in Mação and is divided in three sections:

- respondent's socioeconomic characterization: age, gender, education level, residence and their role concerning forestry or other rural activities;

- their opinion on forest values: types of forest; role and functions of forest sector;

- their perception on issues affecting forest management: problems and constraints affecting forest, drivers and associated factors, measures and solutions to improve forest management

The second questionnaire (Q2) included nine main closed questions and five sub-questions mainly related to a general characterization of the forest owner profile and the type of management used by forest owners living in the municipality of Mação.

The sample included 353 respondents, including 13 technicians from national and regional entities, 17 technicians and other stakeholders from local governmental organizations, nongovernmental organizations and 323 inhabitants from Mação, including 208 forest owners. The selection of the inhabitants (forest owners and other citizens) was based on quota sampling, using preliminary data from Census 2011, Statistics Portugal. In 2011, there were 6,497 inhabitants above 18 years old living in Mação and 5\% of those inhabitants were randomly approached by the interviewers in public areas, such as streets, gardens, public facilities, etc., to complete the questionnaires. As this procedure was not based on a random sample, answers were obtained from all the people who answered the questionnaire. The quota sample was built based on the characteristics of the population, in terms of gender, age group, level of literacy and main source of income (Table 1). Generally, respondents were evenly distributed by gender, but more than $40 \%$ of the respondents were older than 64 , without much education and living on old age pensions. Data was analysed using PASW (Power of Advanced Statistic Analysis) Statistics 18 software, through frequency and cross-tabulations and bivariate analysis, particularly non-parametric tests, such as the Chi-square test of independence and Cramer's V in order to measure the association among different variables. 


\section{Results on stakeholder perceptions}

\subsection{Who has a stake in forest management?}

\subsubsection{National and local technicians}

Policy makers and forestry technicians have an important role to play in forest management and planning. Not only because they contribute to designing policies, regulations, planning and management tools but also in supporting and monitoring the implementation of those instruments. Therefore, the differences between the perceptions of local and national technicians were analysed in this respect.

The surveyed national and local technicians (30 respondents) were mainly men (77\%), aged between 30 and 64 years old (63\%), with a university degree (60\%), mostly involved in forestry sciences or engineering, or with a high school degree (33\%). All local technicians (17 respondents) live in the municipality of Mação. The national technicians (13 respondents) were all employees within the entity they represented in the survey.

When asked to identify the major aims of their organizations related to forest and forestry, the answers differed according to the level of intervention (Table 2). On a local level, fire prevention and mitigation was the most important function. From the 13 national technicians interviewed nine belonged to the public authority for forests (ICNF - National Institute for Conservation of Nature and Forests), indicating the exploitation of the forest, the support of the forest private sector, the fire prevention and the restoration of burned areas as the main functions of that entity (Table 2). The conservation of biodiversity and the promotion of sustainable forest management were also mentioned by national and regional technicians.

\subsubsection{Forest owners and other citizens}

The survey included 323 inhabitants (208 forest owners and 115 other citizens) living in the Mação municipality. The characteristics of this group of respondents are presented in Table 1. In general, respondents were similarly divided between men and women. Over $40 \%$ were over 64 , most had an elementary school degree or were illiterate and almost $50 \%$ were retired (Table 1). The main former or current economic occupation of the respondents was as follows: suppliers, service providers and sales people (24\%); farmers (21\%); and industry workers $(19 \%)$. In the past, agriculture represented the main economic activity in the municipality. However, only $10 \%$ of the active respondents identified themselves as full-time farmers. 
Forest owners represented $64 \%$ of the inhabitants' sample and were also evenly distributed between men and women and by all the Mação parishes. The main socio-demographic difference between forest owners and other citizens is age. Forest owners tend to be older $\left(\chi^{2}(5)=55,26, \rho \leq 0,05\right)$. In fact, most forest holdings were inherited and therefore the owners generally keep the land registry until an advanced age. Some minor differences were also found in terms of education. Though the rate of illiteracy was similar for forest owners and other citizens (around 17\% each), 50\% of the forest owners interviewed had only completed elementary school. More than $50 \%$ of the forest owners were retired.

The forest in the municipality of Mação is owned by small-scale private forest owners. The forest owners interviewed indicated the approximate number and the medium size of their plots, showing that each owner has a variable number of forest plots (one third has less than five plots; one third has between five and 10 plots; and one third has over 10 plots) with an average size of 0.5 ha (Table 3 ). In terms of forest management and planning, these scattered and fragmented plots represent a huge constraint because they demand high forestry intervention and operation costs, and have substantially lower market competitiveness. The use of the forest is therefore limited, difficult to manage and susceptible to forest fires.

\subsubsection{The role of stakeholders in forestry intervention}

Nowadays, almost a quarter of the forest owners surveyed do not actively manage their properties while the majority (73\%) take care of their properties alone (Figure 2). Although 14\% of the forest owners questioned identified themselves as members of a ZIF, only $2 \%$ are actually managing their properties within a management organization (Figure 2).The standard chi-squared test of independence showed evidence of an association between the size of the plots and the type of management $\left(\chi^{2}(2)=6.22, \rho \leq 0.05\right)$, highlighting that forest owners with plots smaller than 0.5 ha do not often carry out work on their properties.

As far as the types of forestry intervention are concerned, 93\% of the 151 forest owners managing their own properties indicated the implementation of elementary measures to help reduce the risk of fires. This included clearing forest scrub, thinning and pruning (Figure 2). Many forest owners also mentioned logging and new plantations (Figure 2). Despite the identification of forestry practices by most of the respondents, the forest of Mação shows itself to be highly vulnerable to fire because the vegetation has not been cleared away properly and so it starts to grow again. There is also no balance in the forest, with extensive areas of monoculture and the absence of buffer areas. 
The answers to the question 'who should be responsible for defining forestry interventions?' were evenly distributed by the Municipal Council, the forest owners' organizations and individual forest owners. The responsibility for the implementation of forest interventions was attributed by all to the same stakeholder groups, but the individual forest owners were mentioned more frequently than the Municipal Council and the forest owners' organizations (Table 4). The differences in the perceptions amongst local inhabitants (be they forest owners or not) were mainly related to their area of residence. In the parish of Carvoeiro (which was not affected by fire and had no ZIF), $80 \%$ of the respondents identified individual forest owners as being those responsible for defining and implementing forestry actions. The respondents from the parish of Ortiga, which has a ZIF and tradition of landowners' cooperation, highlighted the importance of the role of forest owners' organizations (referred to by half of the respondents). In both parishes, the role of the Municipal Council was considered to be less important compared to the respondents living in the other parishes. ZIF members included in the survey also gave more value to the role of forest owners' organization.

If we take the national and local technicians into consideration, the major responsibility was attributed to forest owners' organizations, either in defining or in implementing forestry actions. These respondents downplayed the role of individual forest owners in the definition of forestry actions.

\subsection{What is at stake in the Mação forest?}

\subsubsection{Functions of forests}

Respondents were asked to identify the three most important functions of forest in the Mação municipality. A list with 12 functions was provided, varying from economic functions (timber production, employment), to environmental conservation and protection functions (biodiversity, soil and water conservation, carbon sequestration) and to cultural and social services (aesthetics, leisure time, sports, etc.).The function that was mentioned above all others in the survey was timber production - by $92 \%$ of the national technicians, by all local technicians and by more than $70 \%$ of the forest owners and other citizens surveyed (Figure 3 ).

In fact, the economic role of forest was prominent in both technical and social perceptions, where around $60 \%$ of the answers referred to the productive function of forests (timber and nontimber products) and the forest's role in local employment. This economic vision of forests was even stronger in the technicians' opinions, as the three functions that were mentioned most by local and national technicians were in fact economic ones. The production of timber and the 
other economic functions were considered as important for forest owners as for other citizens alike (Figure 3). This can represent a hidden contradiction between forest owners' perceptions and actions because despite the fact that they perceive the economic role of their forest, they are not willing to invest in them. This is possibly linked to the actual size of the land involved or the fact that it divided into several different areas.

The second topic that was mentioned most by forest owners and people in general was the vital role of forest as a source of fresh air (Figure 3). This factor was more frequently mentioned by female respondents ( $41 \%$ of women compared to $28 \%$ of men included in the survey). This issue reinforces the idea that local inhabitants perceived their places of residence as being more healthy and pleasant to live in than urban areas. For $46 \%$ of the national technicians and $29 \%$ of the local technicians, the forest of Mação has an important role to play in fighting desertification. Biodiversity conservation was also identified by $20 \%$ of the technicians. Both the role in fighting desertification and the role in conservation were hardly mentioned by forest owners or by other citizens. Around $25 \%$ of forest owners and other citizens surveyed identified the forests as an important contribution to aesthetics and to the promotion of leisure activities within the municipality (Figure 3), especially by younger respondents.

\subsubsection{Expected type of forests}

Forests and shrub land represent more than $85 \%$ of the Mação municipality territory. In order to assess whether stakeholders were satisfied with the type of forests, people were asked what kind of forests they would prefer to see in Mação. The results showed that the preferred forest types were the maritime pine production areas, mentioned by all respondents (Figure 4). National and local technicians were more in favour of eucalyptus areas than the forest owners and the other citizens (Figure 4). Cork areas as well as areas with multiple uses were also mentioned most by national and local technicians (Figure 4). These results highlight the importance of the maintenance of already present species (maritime pine and eucalyptus), both in technical and social perceptions. The importance of seeing the multiple uses of the forest, such as grazing, hunting, apiculture and conservation, alongside the expansion of native species (e.g. Quercus), were only mentioned by forestry technicians (Figure 4). The conservation of biodiversity was however mentioned by $30 \%$ of the other citizens and recreation areas were mentioned by $18 \%$ of the forest owners and $17 \%$ of the other citizens (Figure 4).

By analysing only the preferences of the forest owners and the other citizens at a significance level of 0.05 , some correlation was found between the preference for eucalyptus areas and the respondents living in two parishes with larger forest areas: Carvoeiro (not affected by recent 
fires) and Amêndoa parishes (severely affected by fire in 2003). The economic value of forest was prominent in the perception of respondents living in villages where forest areas are predominant, independent of whether they have been affected by fire or not. Forest areas for conservation, for leisure activities, for multiple uses and cork production were given preference by younger and more educated respondents, who were probably more aware of the multifunctionality of forests.

\subsection{What is hindering Sustainable Forest Management?}

\subsubsection{The main problems affecting forests and forest management}

Respondents were asked to identify three or four major problems affecting forests and forest management in the municipality of Mação. The findings showed that there was a consensus regarding the major problems. Forest fires were the problem that concerned respondents (both technicians and citizens) the most. However, while national and local technicians have identified other problems as being as important as the fire hazard, wildfires were the major problem for more than $80 \%$ of the forest owners and other citizens (Figure 5). All the main problems that were identified were related either with fire hazard or with socio-economic drivers of fire hazards.

Ageing and depopulation, as well as the abandonment of rural activities were also frequently mentioned by all types of respondent (Figure 5). These problems are related to the whole scenario of rural abandonment and were mentioned less in the parish of Carvoeiro (not affected by fire) when compared to the other Mação parishes (affected by fire).

The major difference between technical and social perspectives emerged when it came to the subject of small-scale forest holdings. These represented a major problem for national technicians (identified by more than $75 \%$ ) and for more than $60 \%$ of the local technicians consulted. The size of forest holdings was not considered as a problem for forest owners or for other citizens (Figure5), because they had inherited the land.

The forest owners' absenteeism and lack of interest was the third most relevant perceived problem for local technicians (by more than $50 \%$ ). This aspect was also mentioned by more than $30 \%$ of both forest owners and other citizens. The fact that vegetal waste not cleared away was also a problem mentioned by $34 \%$ of the forest owners and $27 \%$ of other citizens.

Finding solutions to complex problems is not an easy task and $20 \%$ of the inhabitants surveyed (either forest owners or other citizens) were not able to identify existent or potential solutions to deal with these problems. Forest owners and other citizens identified 10 different measures to 
tackle 12 problems. The solutions identified were the same for both forest owners and other citizens and mainly involve incentives or penalties to compel and promote active forest management (33\% of the inhabitants included in the survey). The definition and implementation of a rural development strategy was also identified by a quarter of the inhabitants. The national technicians have proposed broad and generic solutions, such as: to develop a rural development strategy, invest in planning and rational exploitation of forests and to promote and support forest owners' organizations. Almost $60 \%$ of the local technicians surveyed identified the implementation of a pilot ZIF in Mação or in similar areas as a solution.

\subsubsection{Forest fire hazard}

Fire hazard has been particularly frequent and intense over the last 20 years, not only in the municipality of Mação, but across the whole of Portugal. The worst wildfire ever (in terms of burned area) occurred in 2003. This was identified as the most relevant incident by $42 \%$ of the respondents (all national and local technicians have indicated 2003). Almost half of the respondents did not indicate a specific year, referring to events 10 or 15 years ago. 2005 and 1991 were also mentioned by more than $10 \%$ of the respondents. As far as the direct impact of the fires on the forest owners themselves are concerned, it was observed that $92 \%$ of the forest owners included in the survey reported that their properties had already been affected by fires (once or twice).

Respondents were asked to identify the causes of forest fires in Mação, distinguishing between ignition causes and causes for the spread of fires. Two main causes of ignition were identified, but the answers were weighted differently among the various stakeholder groups questioned. While forest owners and other citizens clearly identified the arsonists as being the major culprits, local technicians were divided between arsonists and negligence (Figure 6). The indication of arson was lower among national technicians when compared with the other groups (Figure 6).

The perception of the main causes for fire spreading varied according to the relationship people had with Mação itself. Local technicians, forest owners and other citizens shared a similar opinion and affirmed that a main factor was most certainly the fact that forests were not cleared and thinned properly. Another factor is the climatic conditions in the area, namely high temperatures, low rainfall and strong winds (Figure 7). The absence of forestry clearing and thinning was also mentioned by $70 \%$ of the national technicians (Figure 7 ). They also mentioned the absence of buffer areas, which were traditionally agricultural valleys or grazing areas. Half of national technicians also indicated the presence of highly combustible species (e.g. eucalyptus) and the lack of fire breaks and strips for fuel management (Figure 7). 


\section{Discussion and Conclusions}

\subsection{The role of forests and forestry}

Contrary to one of the initial assumptions, where it was stated that forests and forestry are increasingly valued for their environmental amenities, the survey's findings have highlighted the importance of the productive function of forest in the municipality of Mação, not only from a public perspective, but also from a key-stakeholder's perspective. This can be explained by the history of forest cover and the geographical and socio-economic characteristics of the area. Portuguese forest area have increased either through state plantations or in most cases through plantations carried out by private owners, especially to meet economic goals, rather than environmental purposes (Coelho, 2002; Coelho, 2003; Baptista and Santos, 2005). This was reflected in the central region of Portugal which is made up mainly of afforestation or reforestation areas with Pinus pinaster and Eucalyptus globulus.

The lack of an environmental perspective mentioned by the public which is shown in this survey could well be linked to the existent type of forest species, which are focused mainly on timber production and to pulp industries. This is in line with some studies which found more negative perceptions about forests and forestry in Atlantic countries and afforestation areas, when compared to central and Mediterranean Europe countries and traditional forest areas (Elands et al., 2004; Ní Dhubháin et al., 2009). However, the EC survey (2009), which included data from Portugal, went in a totally different direction and showed that $60 \%$ of the Portuguese respondents $(\mathrm{N}=353)$ ranked forest protection as their priority. But this finding is probably related to forest protection against fire and less with the conservation of biodiversity and climate change mitigation, because wildfires were also identified in the study as the major global concern for the Portuguese forest.

The awareness of the environmental value of forests is still not really an issue both from farmers and forest owners alike. This was also evident in terms of the impacts of fires, where forest owners are more concerned with the economic impacts of fires (Ribeiro et al., 2014). Environmental awareness mainly springs from external pressure (Baptista and Santos, 2005). This was also observed in the Mação municipality, where the preferences of forest owners and of other local inhabitants concerning the suitable type of forest for Mação were quite similar to the existing forest - maritime pine and eucalyptus. However, some resistance to the eucalyptus was found on a local scale, because these areas were seen as suitable by less than a quarter of the inhabitants. The technicians also indicated the importance of production areas. However, 
within this group the multiple uses of forests, the cork areas and the role of forest in fighting desertification and for soil and water conservation were important aspects.

A neglected aspect within the European surveys (EC, 2009) was the recreational function of forests. This aspect and the role of the forest to local aesthetics were valued issues in the municipality of Mação, especially among the local population. This might be related to public and private investments in leisure areas and infrastructures within the municipality.

\subsection{Wildfires as a major constraint to forest management}

The survey's findings have confirmed that wildfires are perceived to be a major constraint to forest management in the Mação municipality. It was identified as the major problem affecting the forest areas in the case study. All the respondents had experienced several forest fires and more than $90 \%$ of the surveyed forest owners had been directly affected. This was not only observed in the Mação case study but also in other areas of central Portugal where perception surveys were carried out (e.g. Ribeiro et al., 2010). In fact, official data and social perceptions are the same when it comes to the issue of fire as being the main problem affecting forests in Mediterranean Europe and in Portugal. Portuguese public opinion indicates that wildfires are a real and a major threat to forests' health and vitality (EC, 2009; Galante et al., 2009), and a significant environmental problem in Portugal (Almeida, 2001; Delicado and Gonçalves, 2007). This could be linked to the succession of forest fires on a yearly basis and also to the intense attention media gives to this topic during the summer.

The social risk perception relies on an intuitive evaluation of the risk, integrating qualitative reflections like fear, the potential for catastrophes, trust in management, familiarity with the source of risk and acceptance or degree of control over the risk (Slovic, 1987; Flynn and Slovic, 2000; Figueiredo et al., 2009). In this sense, experiencing an event can sometimes help people to reduce the perceived risk and even cope with it (e.g. Figueiredo, et al., 2009; Valente et al., 2007; Valente et al., 2011b). This is not the case of fire hazard, where its catastrophic potential and the widespread public feeling of having no control over it (Galante et al., 2009) have made forest fires the key concern when it comes to the perception of forests in Portugal.

The findings of this study show that the social perception of the causes of fire in Mação are related to arson or negligence and are aggravated by climatic conditions and by rural and land abandonment. This is confirmed by the European and national institutional reports (FAO, 2007; MADRP, 2005) and by other studies (Piussi and Farrell, 2000; Colaço, 2006; Damasceno and Silva, 2007; Galante et al., 2009; Coelho et al., 2012; Ribeiro et al., 2013; Ribeiro et al., 2014). 
Some public opinion studies on social perceptions regarding forest fires have shown that many forest owners claimed to manage their forests and to invest some money in their properties (Galante et al., 2009; Ribeiro et al., 2010). European experts also considered that the general public usually see their forest management practices as positive (EC, 2009). The present study identified some controversial findings on this topic. On the one hand, more than $70 \%$ of the forest owners included in this survey indicated some management activities in their properties (such as clearing, thinning and pruning). On the other hand the abandonment of rural activities, the lack of forest clearing and landowners' absenteeism were identified by all stakeholder groups as important problems in the municipality of Mação.

The assumption that the absence of forest management is recognized as a main reason for forest fires - which are the major threat to forests in Portugal - can be confirmed by the Mação case study. However, forest owners and inhabitants in Mação did not recognize their direct responsibility towards the problem, which is line with the Galante et al. (2009) findings. In Mação, the fast natural regeneration of the vegetation and the absence of forestry intervention have been leading to a cycle of repetitive and successive wildfires. In this sense, small-scale forest owners often believed that no intervention is the most reasonable decision (Radich and Baptista, 2005) because they do not see that their investments will be compensated for in the future. This problem is of huge significance, especially considering that just one individual decision about 0.5 ha of forest can affect other contiguous forest owners' decisions, thus starting a very negative snowball effect. The influences of social surroundings were also mentioned as being an important factor for forest management practices in the Bieling (2004) study. Additionally, land structure, which was identified as a huge problem by key-stakeholders was not recognized at all by local inhabitants as being an issue for forest management.

\subsection{The role of forest owners in forest management}

The findings from the survey have shown evidence which confirms part of the first theoretical assumption, namely a shift from classic owners so-called hobby owners or indifferent owners which is occurring in private small-scale forest holdings. Thus, the municipality of Mação has seen a transition from classic and economic-oriented forest owners, where forest owners lived from agriculture and forestry, to the emergence of indifferent owners with no interest in the forest besides owning it and keeping it within the family or as a reserve for the future. This can be illustrated by the change of the main economic occupations of the forest owners included in the survey. While almost $40 \%$ of the forest owners which are retired had indicated agriculture, forestry and fishery as their former job, only $15 \%$ of the active forest owners maintain agriculture 
and other related activities as their main economic activity. In that sense, forestry and agriculture are no longer the main source of income, and people are living from retirement pensions or from wages from the other activities, changing the management perspectives over the sector.

This idea is also supported in other studies where the classic forest owner is giving way to new types of forest owners, described as hobby owners, who only have a modest interest in forestry and only a limited recognition of the environmental role of forestry (Boon, et al., 2004), or the indifferent owners with even less interest in the forest because of its insignificant economic value to the household income (O'Leary and Elands, 2002; Baptista and Santos, 2005; Wiersum et al., 2005).

The typical profile of forest owners has shown that besides the absentee owners who live in the city, forest owners living in Mação tend to be over 60 years old and/or retired, and hold relatively small tracts of maritime pine and eucalyptus. They do not depend economically upon the forest and usually make no or very little investment in their properties. Nevertheless, these owners are quite attached to the idea of the forest as a legacy. Mação forest owners used to combine agriculture, grazing and forestry activities as full time activities. However, due to the migration of people from rural to urban areas in search of new opportunities and due to the intense wildfires, the forest owners have changed into a more indifferent kind of owner, who owns smaller forest plots and does not have economic or other objectives as far as the forest itself is concerned.

Most of the forest owners surveyed said that they make small interventions in the forests, such as clearing away vegetal waste, thinning, pruning and logging. This has also been observed in other studies in Portugal, where most forest owners also mentioned 'managing' their properties (Galante et al., 2009; Ribeiro et al., 2010). However, in the municipality of Mação, it has become increasingly hard to find forest areas with any form of management. The type of forest owners described as hobby owners, who emphasized the multifunctional role of forestry, were not identified as a group in the survey. In fact, the forest owners surveyed did not give any relevant value to the environmental role of forests.

Small-scale forest holdings in Portugal are mostly seen as a family inheritance and an economic reserve, which along with fire hazard, leads to the idea which is supported by many small-scale forest owners, namely that no intervention is the only viable solution for their properties (Radich and Baptista, 2005). The findings also showed this sense of ownership, where the landowners' organizations were not recognized by most of the forest owners and other inhabitants as a solution and the small scale forest itself was not mentioned as a problem. Another study about 
Portuguese forest owners also revealed that only a minority of private forest owners participated in forest owners associations, and they thought that these organizations should carry out tasks according to their individual interests (Baptista and Santos, 2005). In the municipality of Mação, forest owners' organizations have made the first step with the creation of the forest association of Mação - AFLOMAÇÃO - and the ZIF approach development.

There is widespread awareness that there is a need for the joint intervention of forest owners, both for national key-stakeholders, as well as for local key-stakeholders. This was evident in the findings, where great support was given to ZIF implementation both at local and national levels. If the landowners' organizations do not work in small-scale private forest areas, the only possibility left will be to let the state take care of forest areas owned by absentee forest owners (Borges e Amaral, 2009). In both cases knowing who the forest owners are and knowing what their values, preferences, interests and behaviours are, is of upmost importance.

The survey highlights a strong contradiction between forest owner's perceptions and their actual actions. Most of them said that they maintained some management activities on their properties, but in fact the lack of forest management is an important social concern and a major cause of forest fires. It is very important to understand the reasons behind the increasing disinterest and absenteeism and to find the best ways of promoting active forest management, while also meeting the individual interests and values of forest owners. The importance of including local characteristics and promoting stakeholder involvement in decision-making has been highlighted in other recent studies (Carreiras et al., 2014; Ribeiro et al., 2014).

\section{Acknowledgements:}

The research described in this paper was conducted within the framework of the Ph.D. Grant of Sandra Valente (SFRH/BD/47056/2008) and of ForeStake project (PTDC/AGRCFL/099970/2008), funded by FCT with co-funding FEDER, through COMPETE (Programa Operacional Fatores de Competitividade). The authors also acknowledge the EU-FP7 funded CASCADE (Catastrophic shifts in drylands: how can we prevent ecosystem degradation?) project. We would like to thank to: António Louro, Nuno Bragança, Inês Mariano and João Fernandes for kindly providing all the necessary information; João Pinho, Andreas Kläy, José Portela for valuable feedback on the questionnaire design; and João Soares, Teresa Carvalho and Joana Silva for helping in the questionnaire implementation. Thanks to Georgina Hodge for proofreading and to the reviewers for valuable suggestions. Finally, a grateful acknowledgement is owed to all anonymous respondents who made this research possible. 


\section{References:}

AFN, 2010. Apresentação do Relatório Final do 5 Inventário Florestal Nacional. Lisboa: Autoridade Florestal Nacional, Ministério da Agricultura, Desenvolvimento Rural e Pescas.

Almeida, J.F., 2001. Os Portugueses e o Ambiente, II Inquérito Nacional - Resumo. Oeiras: Celta Editora, $41 \mathrm{pp}$.

Baptista, F.O. and Santos, R., 2005. Os Proprietários Florestais. Oeiras: Celta Editora, 94 pp.

Bieling, C., 2004. Non-industrial private-forest owners: possibilities for increasing adoption of close-tonature forest management. European Journal of Forest Research 123(4): 293-303.

Boon, T., Meilby, H. and Thorsen, B., 2004. An Empirically Based Typology of Private Forest Owners in Denmark; Improving Communication Between Authorities and Owners. Scandinavian Journal of Forest Research 19(4): 45-55.

Borges, C. and Amaral, M.R., 2009. Os Serviços Públicos Florestais terão razão para Existir. In: 6.ำ Congresso Florestal Nacional - a floresta num mundo globalizado. Ponta Delgada: Sociedade Portuguesa de Ciências Florestais, 6-9 October 2009, pp. 838-843.

Carreiras, M., Ferreira, A.J.D., Valente, S., Fleskens, L., Gonzales-Pelayo, O., Rubio, J.L., Stoof, C.R., Coelho, C.O.A., Ferreira, C.S.S., and Ritsema, C.J., 2014. Comparative analysis of policies to deal with wildfire risk. Land Degradation and Development 25: 92-103.

CNR, 2005. Orientações estratégicas para a recuperação das áreas ardidas em 2003 e 2004. Lisboa: Ministério da Agricultura, do Desenvolvimento Rural e das Pescas, Secretaria de Estado do Desenvolvimento Rural e das Florestas, Conselho Nacional de Reflorestação, 80 pp.

Coelho, C., Ribeiro, C., Valente, S. and Figueiredo, E., 2012. Relatório de Análise dos Inquéritos por Questionário realizados aos Gabinetes Técnicos Florestais e Associações Florestais - Projeto ForeStake. Aveiro: Universidade de Aveiro, Fundação para a Ciência e Tecnologia, 24 pp.

Coelho, I.S., 2002. Land Tenure as an Influence Factor on the Portuguese Forest Policy. In: COST E-19 National Forest Programmes in a European Context. Sopron. In: http://www.metla.fi/eu/cost/e19/seita.pdf (last accessed: 9 January 2012).

Coelho, I.S., 2003. Propriedade da Terra e Política Florestal em Portugal. Silva Lusitana 11(2): 185-199.

Colaço, M.C., 2006. Are the forest technician's fire perceptions connected to the Portuguese reality? Cross over the official and research data with the results of a national inquiry. Forest Ecology and Management 234S: S17.

Conacher, A. and Sala, M., 1998. Land Degradation in Mediterranean Environments of the World: Nature and extent, causes and solutions. Chichester: John Wiley \& Sons, Ltd, 512 pp. 

a floresta: Incêndios, pragas e doenças. Coleção Árvores e Florestas de Portugal 08. Lisboa: Público, Comunicação Social, SA and Fundação Luso-Americana para o Desenvolvimento, pp. 41-67.

Delicado, A. and Gonçalves, M.E., 2007. Os portugueses e os novos riscos: resultados de um inquérito. Análise Social XLII(184): 687-718.

Deus, E., 2010. A implementação do conceito Zona de Intervenção Florestal em Portugal - o caso do concelho de Mação. Dissertação apresentada para obtenção do grau de Mestre em Geografia Física, Ambiente e Ordenamento do Território. Coimbra: Faculdade de Letras, Universidade de Coimbra, 112 pp.

Dolisca, F., McDaniel, J.M. and Teeter, L.D., 2007. Farmers' perceptions towards forests: A case study from Haiti. Forest Policy and Economics 9: 704-712.

EC, 2002. Perception of wood-based industries: Qualitative Study. Brussels: European Commission, Office for Official Publications of the European Communities, $71 \mathrm{pp}$.

EC, 2009. Shaping forest communication in the European Union: public perceptions of forests and forestry. Brussels: European Commission, DG Agriculture and Rural Development, 157 pp.

Elands, B.H.M., O'Leary, T.N., Boerwinkel, H.W.J., and Wiersum, K.F., 2004. Forests as a mirror of rural conditions; local views on the role of forests across Europe. Forest Policy and Economics 6(5): 469-482.

Elands, B.H.M. and Praestholm, S., 2008. Landowners' perspectives on the rural future and the role of forests across Europe. Journal of Rural Studies 24(1): 72-85.

Elands, B.H.M. and Wiersum, K.F., 2001. Forestry and rural development in Europe: an exploration of socio-political discourses. Forest Policy and Economics 3(1-2): 5-16.

Fabra-Crespo, M., Mola-Yudego, B., Gritten, D. and Rojas-Briales, E., 2012. Public perception on forestry issues in the Region of Valencia (Eastern Spain): diverging from policy makers? Forest Systems 21(1): 99-110.

FAO, 2007. Fire management - global assessment 2006. FAO Forestry Paper 151. In: http://www.fao.org/docrep/009/a0969e/a0969e00.htm (last accessed: 6 February 2010).

Fernandes, P.M., 2007. Entender porque arde tanto a floresta em Portugal. In: J.S. Silva (Ed.), Proteger a floresta: Incêndios, pragas e doenças. Coleção Árvores e Florestas de Portugal 08. Lisboa: Público, Comunicação Social, SA and Fundação Luso-Americana para o Desenvolvimento, pp. 69-91.

Figueiredo, E., Valente, S., Coelho, C. and Pinho, L., 2009. Coping with risk analysis on the importance of integrating social perceptions on flood risk into management mechanisms - the case of the municipality of Águeda, Portugal. Journal of Risk Research 12(5): 581-602. 
Fléchard, M., Ní Dhubháin, A., Carroll, M., Cohn, P., 2006. Forestry and the local community in Ireland: A Case Study in the Arigna Region. Small-scale forestry and rural development - The intersection of ecosystems, economics and society. Proceedings of IUFRO 3.08 Conference, Dublin COFORD, pp.8192.

Flynn, J., and Slovic, P. 2000. Avaliações dos peritos e do público acerca dos riscos tecnológicos. In: M.E. Gonçalves (Ed.), Cultura científica e participação pública. Oeiras: Celta, pp. 109-120.

Forestry Commission, 2011. Public Opinion of Forestry 2011, UK and England. Edinburgh: Forestry Commission, Economics \& Statistics, $37 \mathrm{pp}$.

Galante, M., Alves, P.I., Cavaco, V., and Miguel, M., 2009. A percepção da população portuguesa sobre Incêndios Florestais e as suas causas. In: 6. Congresso Florestal Nacional - a floresta num mundo globalizado. Ponta Delgada: Sociedade Portuguesa de Ciências Florestais, 6-9 October, pp. 873-882.

Heino, J. and Harvonen, J., 2003. Forests - an integrated part of Finnish life. Unasylva 54(213): 3-9.

JRC/EC, 2010. Forest Fires in Europe 2009. Report N.⒑ Luxembourg: Joint Research Centre/ European Commission, 75 pp.

Kline, J.D., Alig, R.J. and Johnson, R., 2000. Fostering the Production of Nontimber Services Among Forest Owners with Heterogeneous Objectives. Forest Science 46(2): 302-311.

MADRP, 2007. Plano Estratégico Nacional Desenvolvimento Rural (2007-2013). Lisboa: Ministério da Agricultura, Desenvolvimento Rural e Pescas, 84 pp.

Mendes, A., 2003. O Sector Florestal Português - Necessidades de organização colectiva do sector privado e medidas de política pública urgentes. In: J. Portela and J. Caldas (Eds.), Portugal Chão. Oeiras: Celta Editora, pp. 359-372.

Ní Dhubháin, A., Fléchard, M-C., Moloney, R. and O'Connor, D., 2008. Stakeholders' perceptions of forestry in rural areas-Two case studies in Ireland. Land Use Policy 26(3): 695-703.

O'Leary, T.N. and Elands, B.H.M., 2002. Anyone for more forests? Current perspectives and future expectations on afforestation and forest functions across Europe. In: K.F. Wiersum and B.H.M. Elands, The changing role of forestry in Europe: perspectives for rural development. International Policy Research Symposium. Wageningen: Forest and Nature Conservation Policy Group, University of Wageningen, pp. $51-74$.

Pinho, J., Louro, G. and Paulo, S., 2005. A Recuperação de Áreas Ardidas em 2003. Orientações Estratégicas. In: 5. Congresso Florestal Nacional - a Floresta e as Gentes, Viseu: Instituto Politécnico de Viseu, 16-19 May. In: http://www.esac.pt/cernas/cfn5/docs/T5-17.pdf (last accessed: 15 June 2009).

Piussi, P. and Farrell, E., 2000. Interactions between society and forest ecosystems: challenges for the near future. Forest Ecology and Management 132(1): 21-28. 

13(2): 143-157.

Rametsteiner, E. and Kraxner, F., 2003. Europeans and Their Forests: What Do Europeans Think About Forests and Sustainable Forest Management? Vienna: MCPFE/FAO/UNECE: 56 pp.

Rametsteiner, E., Oberwimmer, R. and Gschwandtl, I., 2007. EUROPEANS AND WOOD. What Do Europeans Think About Wood and Its Uses? A Review of Consumer and Business Surveys in Europe. Warsaw, UN-FAO/ECE, 70 pp.

Ribeiro, C., Figueiredo, E., Coelho, C., Valente, S. and Carvalho, T., 2010. Uma árvore não faz a floresta? Análise da percepção dos proprietários florestais face aos incêndios e sua actuação. In: E. Figueiredo, E. Kastenholz, M.C. Eusébio, M.C. Gomes, M.J. Carneiro, P. Batista and S. Valente (Org.), IV Congresso de Estudos Rurais - Mundos Rurais em Portugal: Múltiplos Olhares, Múltiplos Futuros. Aveiro: Universidade de Aveiro, 4-6 February, pp. 172-173.

Ribeiro, C., Valente, S., Coelho, C. and Figueiredo, E., 2013. Portugal a Arder... Visões dos Agentes e das Comunidades Locais sobre Causas e Consequências dos Incêndios Florestais. In: J. Bento, J. Lousada, A. Teixeira (Eds.), 7º Congresso Florestal Nacional - Conhecimento e Inovação, 5-8 de junho, Sociedade Portuguesa de Ciências Florestais, Vila Real/Bragança, p.182.

Ribeiro, C., Valente, S., Coelho, C. and Figueiredo, E., 2012. Visions of local forest technicians' about forest management policies. In: XIII World Congress of Rural Sociology. Lisboa: International Rural Sociology Association, Instituto Superior de Agronomia and Instituto Superior de Ciências Sociais e Políticas, Universidade Técnica de Lisboa, 29 July to 4 August.

Ribeiro, C., Valente, S., Coelho, C. and Figueiredo, E., 2014. A look at forest fires in Portugal: technical, institutional and social perceptions. Scandinavian Journal of Forest Research, DOI:10.1080/02827581.2014.987160

Slovic, P., 1987. Perception of risk. Science 236: 280-5.

Valente, S., Coelho, C., Ribeiro, C. and Soares, J., 2013. Forest Intervention Areas: A new approach for non-industrial private forest management in Portugal. Silva Lusitana 21(2): 137-161.

Valente, S., Soares, J. and Coelho, C., 2011a. Planeamento e Gestão Sustentável do Território: Aplicação da Metodologia WOCAT no Concelho de Mação. In: E. Figueiredo, E. Kastenholz, M.C. Eusébio, M.C. Gomes, M.J. Carneiro, P. Batista and S. Valente (Coord.), O Rural Plural: olhar o presente, imaginar o futuro. Castro Verde: 100Luz, pp. 355-368.

Valente, S., Coelho, C., Figueiredo, E. and Pinho, L., 2011b. Public perceptions of floods in Águeda municipality. In: W.T. Groot and J. Warner (Eds.), The Social Side of River Management. New York: Nova Science Publishers, Inc., pp. 13-26. 
Valkeapää, A. and Karppinen, H., 2013. Citizens' view of legitimacy in the context of Finnish forest policy. Forest Policy and Economics 28: 52-59.

Wiersum, K. F. and Elands, B.H.M. (Eds.), 2002. Nature Forest in society. The changing role of forestry in Europe: perspectives for rural development. Wageningen: Forest and Nature Conservation Policy Group, $171 \mathrm{pp}$.

Wiersum, K., Elands, B. and Hoogstra, M., 2005. Small-Scale Forest Ownership across Europe: Characteristics and Future Potential. Small-Scale Forest Ecomomics, Management and Policy 4(1): 1-19. 


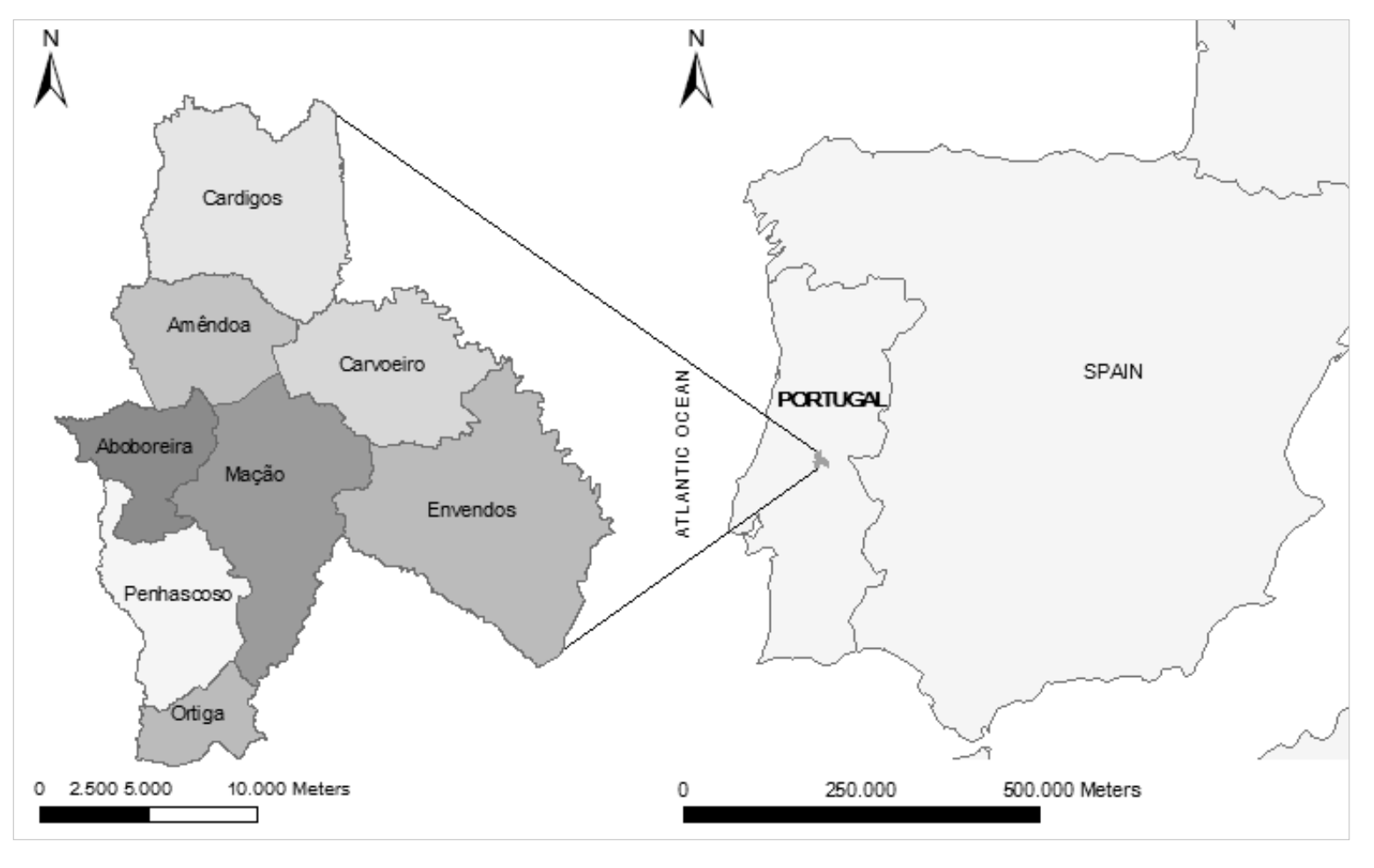

Figure 1: Location of the municipality of Mação

(a) Cardigos

Figure 1: Location of the municipality of Mação

\section{Figure}

.

(1)

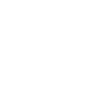

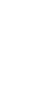

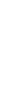

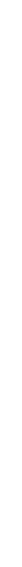

(1)

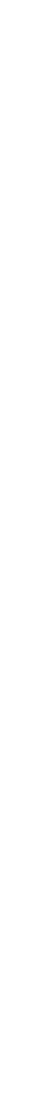

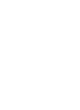

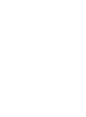

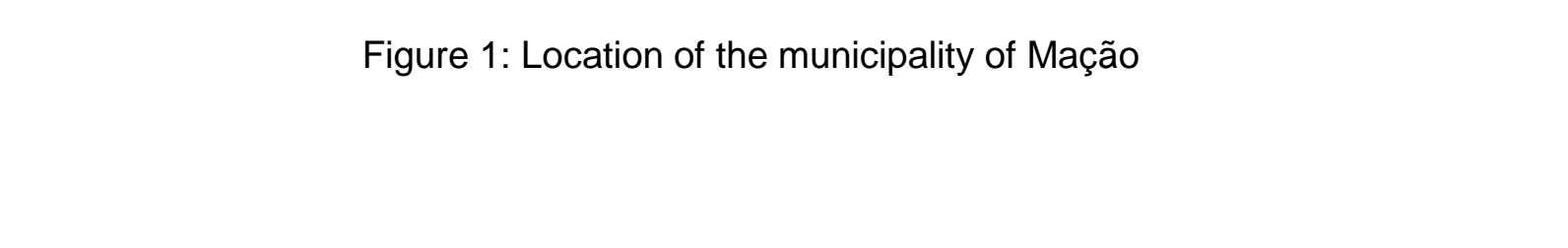




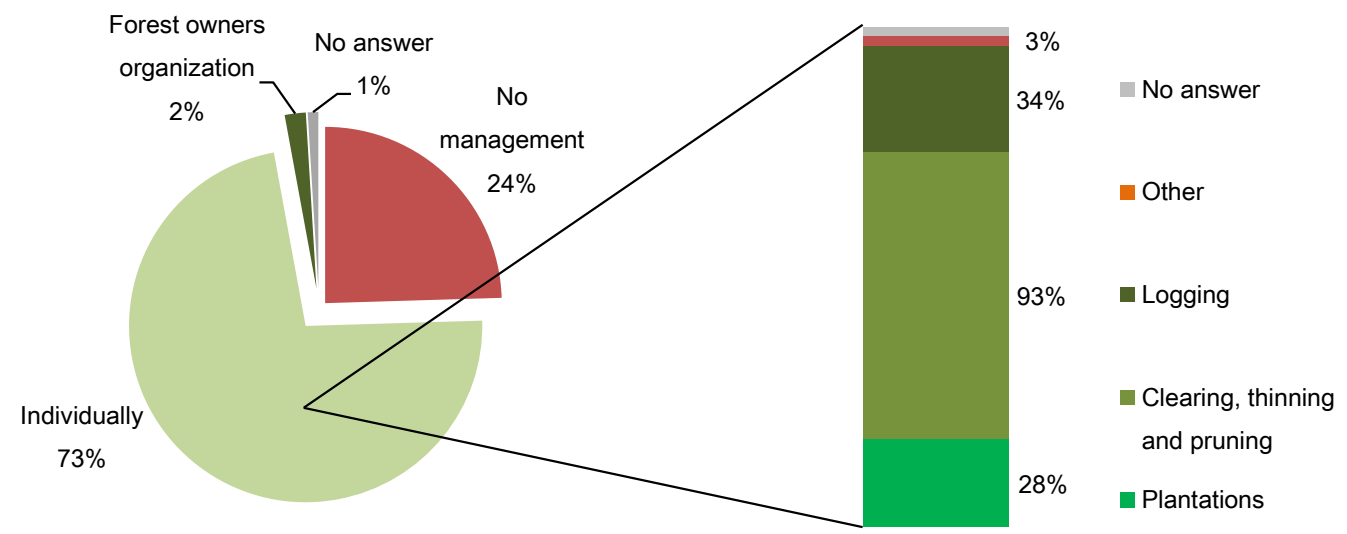

Figure 2: Types of forest management (left graph) and management activities (right graph) as indicated by individual forest owners in the municipality of Mação 
Figure 3

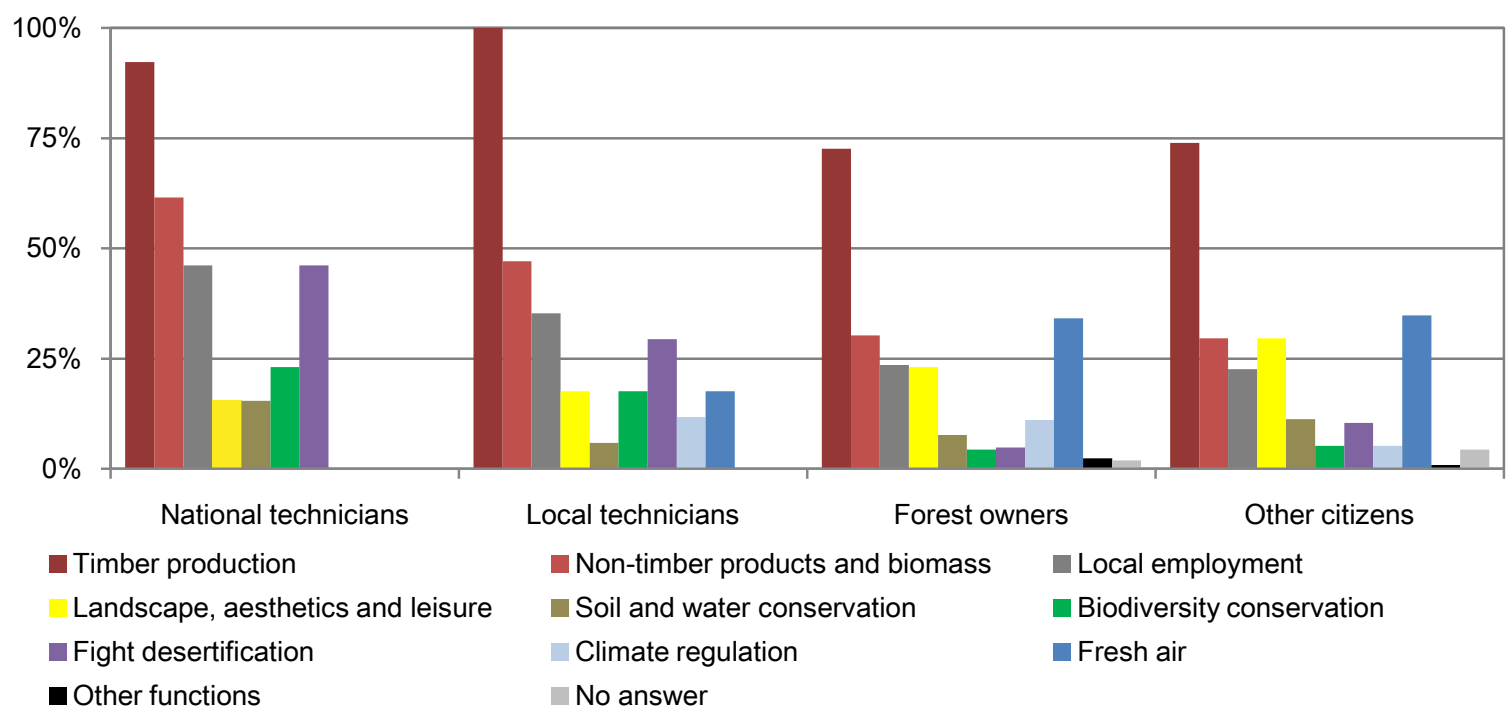

Figure 3: Main functions of forest in the Mação municipality as identified by the different stakeholder 


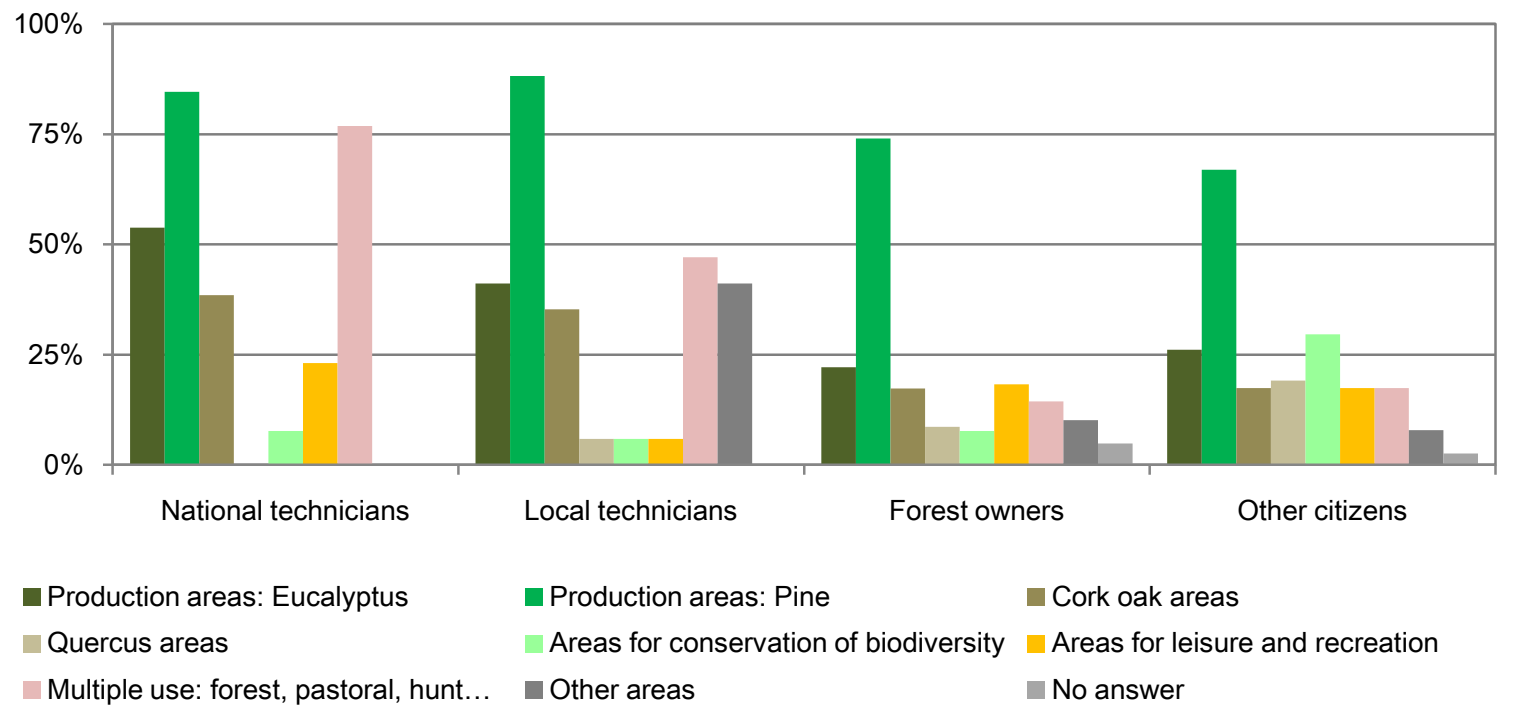

Figure 4: Types of forest preferred to the municipality of Mação as indicated by the different stakeholders 


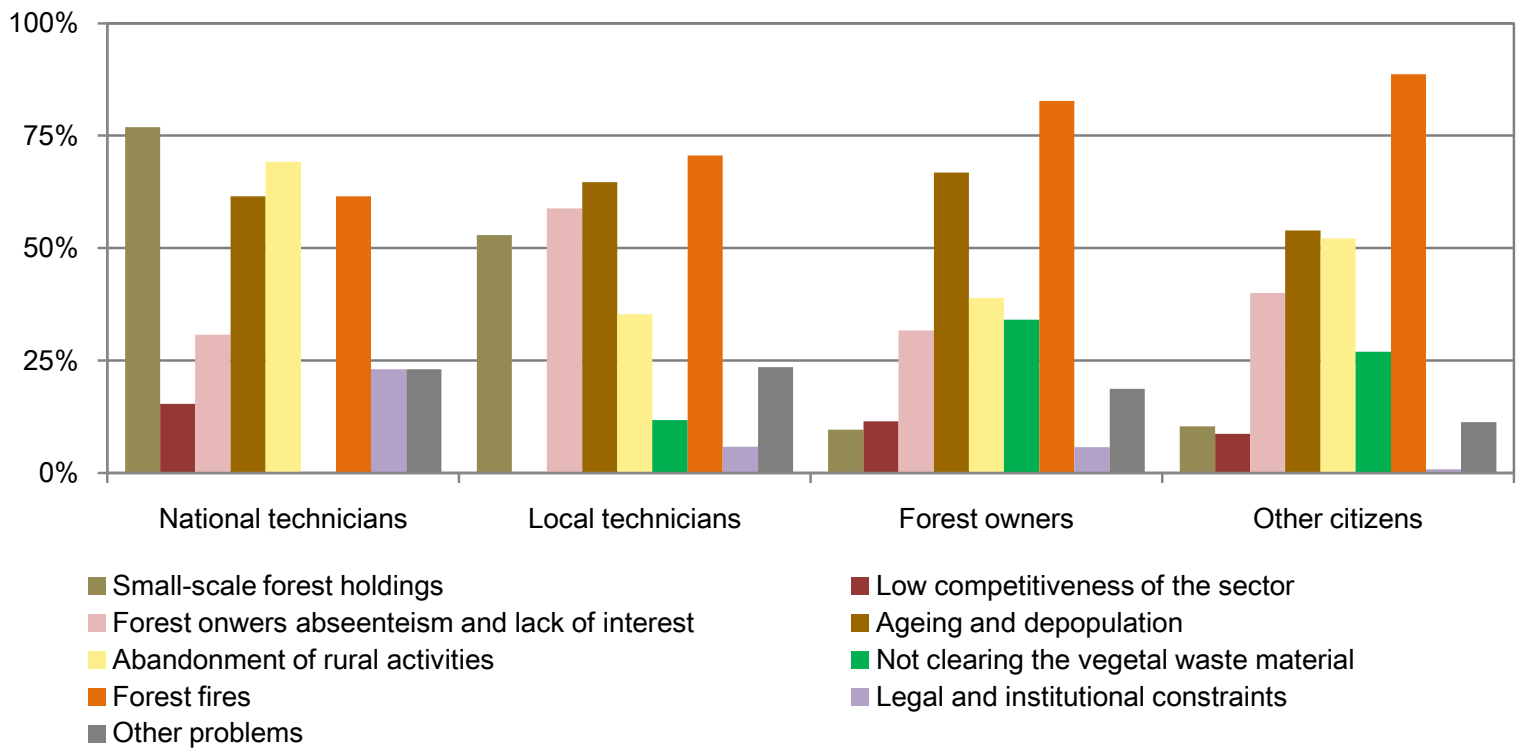

Figure 5: Problems affecting forest management in the municipality of Mação as indicated by the different stakeholders 


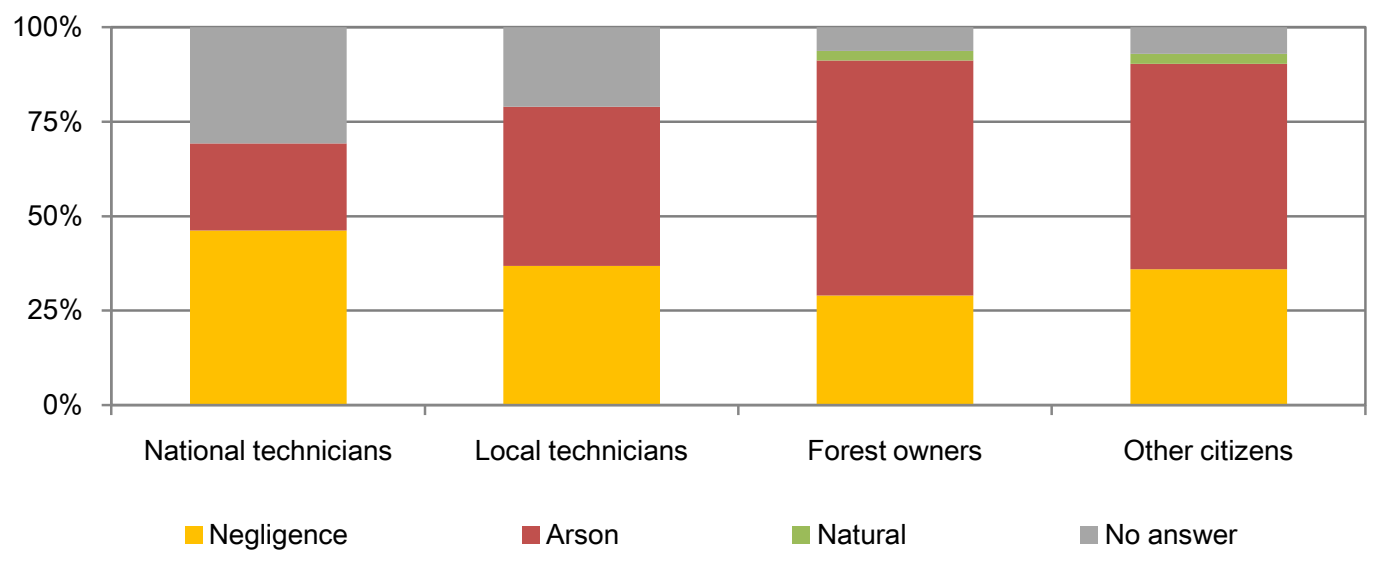

Figure 6: Causes for fire ignition in the municipality of Mação as indicated by the different stakeholders

\section{stakeholders}




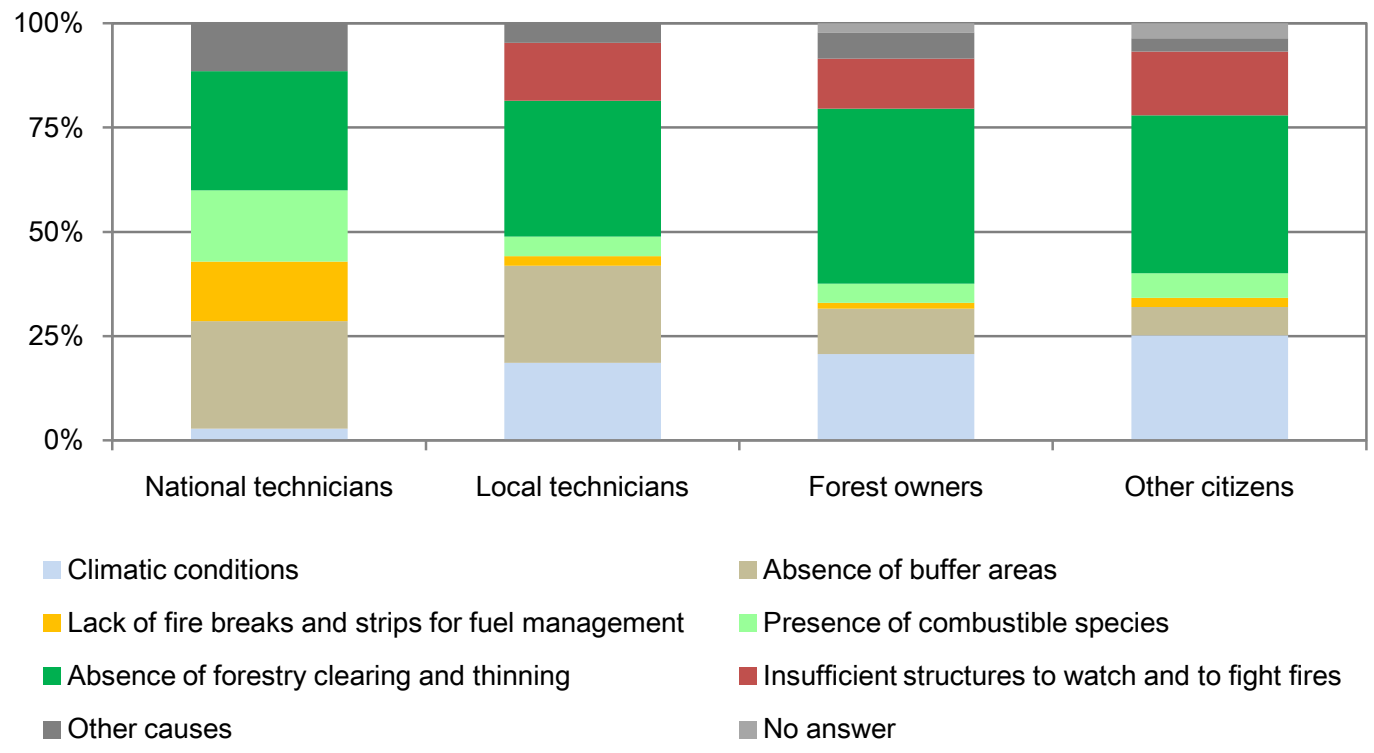

Figure 7: Causes for fire spreading in the municipality of Mação as indicated by the different stakeholders 
Table 1: Inhabitants over the age of 18 and sample distribution per selected criteria

\begin{tabular}{|c|c|c|c|c|c|}
\hline \multicolumn{2}{|c|}{ SAMPLING CRITERIA } & \multirow{2}{*}{$\frac{\text { Inhabitants }}{3040}$} & \multirow{2}{*}{$\begin{array}{c}\text { Proportion (\%) } \\
47\end{array}$} & \multirow{2}{*}{$\begin{array}{c}\text { Sample } \\
153 \\
\end{array}$} & \multirow{2}{*}{$\begin{array}{c}\text { Proportion (\%) } \\
47\end{array}$} \\
\hline GENDER & Male & & & & \\
\hline & Female & 3457 & 53 & 170 & 53 \\
\hline & Total & 6497 & 100 & 323 & 100 \\
\hline \multirow{4}{*}{$\begin{array}{c}\text { AGE } \\
\text { GROUP }\end{array}$} & 18-24 years old & 411 & 6 & 19 & 6 \\
\hline & $25-64$ years old & 3196 & 49 & 161 & 50 \\
\hline & More than 64 years old & 2890 & 45 & 143 & 44 \\
\hline & Total & 6497 & 100 & 323 & 100 \\
\hline \multirow[t]{7}{*}{ EDUCATION } & Illiterate & 1349 & 21 & 55 & 17 \\
\hline & 4th Grade & 2384 & 37 & 128 & 40 \\
\hline & 6th Grade & 658 & 10 & 29 & 9 \\
\hline & 9th Grade & 1015 & 16 & 52 & 16 \\
\hline & High School & 628 & 10 & 30 & 9 \\
\hline & Graduated & 463 & 7 & 29 & 9 \\
\hline & Total & 6497 & 100 & 323 & 100 \\
\hline \multirow{6}{*}{$\begin{array}{c}\text { MAIN } \\
\text { LIVING } \\
\text { SOURCE }\end{array}$} & Work & 2315 & 36 & 116 & 36 \\
\hline & Unemployment benefit & 76 & 1 & 12 & 4 \\
\hline & Old age pension & 3127 & 49 & 147 & 46 \\
\hline & Family care & 817 & 13 & 46 & 14 \\
\hline & Other situation & 109 & 2 & 2 & 1 \\
\hline & Total & 6497 & 100 & 323 & 100 \\
\hline
\end{tabular}




\section{Table 2: The major aims of the organizations as outlined by the respondents}

\begin{tabular}{|l|r|c|c|}
\hline \multirow{2}{*}{ Organization's aims } & National technicians & \multicolumn{2}{|c|}{ Local technicians } \\
\cline { 2 - 4 } & Respondents & $\%$ & Respondents \\
\hline Exploitation of the forest & 6 & 46 & 2 \\
\hline Support of the forest industries & 5 & 39 & 0 \\
\hline Forest fire prevention & 5 & 39 & 11 \\
\hline Restoration of burnt areas & 5 & 39 & 12 \\
\hline Promotion of Sustainable Forest Management & 4 & 31 & 4 \\
\hline Conservation of biodiversity & 5 & 39 & 0 \\
\hline Constitution of Forest Intervention Areas (ZIF) and forest owners awareness & 0 & 0 & 0 \\
\hline Other complementary activities (e.g. hunting, apiculture, fisheries, agriculture, etc.) & 4 & 31 & 5 \\
\hline Other functions & 3 & 23 & 24 \\
\hline Total & 13 & 100 & 29 \\
\hline
\end{tabular}


Table 3: Characteristics of forest plots in the Mação municipality as indicated by respondents

\begin{tabular}{|l|l|c|c|}
\hline Forest ownership & Criteria & Respondents & $\%$ \\
\hline \multirow{4}{*}{ Number of forest plots } & $<5$ & 74 & 35 \\
\cline { 2 - 4 } & $5-10$ & 70 & 34 \\
\cline { 2 - 4 } & $>10$ & 58 & 28 \\
\cline { 2 - 4 } & N.A. & 6 & 3 \\
\hline \multirow{5}{*}{ Average size of the forest plots } & $<0,5$ ha & 95 & 46 \\
\cline { 2 - 4 } & $0,5-2$ ha & 72 & 34 \\
\cline { 2 - 4 } & $2-5$ ha & 25 & 12 \\
\cline { 2 - 4 } & $>5$ ha & 4 & 2 \\
\cline { 2 - 4 } & N.A. & 12 & 6 \\
\cline { 2 - 4 } & Total & 208 & 100 \\
\hline
\end{tabular}


Table 4: 'Who should be responsible by implementing forestry actions?' by type of stakeholder

\begin{tabular}{|l|c|c|c|c|}
\hline Stakeholders & National technicians & National technicians & Forest owners & Other citizens \\
\hline Individual forest owners & 2 & 7 & 110 & 63 \\
\hline Forest owner organizations & 13 & 15 & 72 & 32 \\
\hline Forest enterprises & 1 & 1 & 12 & 17 \\
\hline Municipal council and other local GO & 6 & 5 & 71 & 38 \\
\hline National and regional entities & 13 & 2 & 0 & 0 \\
\hline No answer & 0 & 0 & 25 & 14 \\
\hline Total & 13 & 17 & 208 & 115 \\
\hline
\end{tabular}

